\title{
Inorganic lanthanides induce PCR bias towards shorter amplicons
}

\author{
Fan Li ${ }^{\ddagger 1}$, Hongwei Sun ${ }^{\ddagger}, 1$, Shuke Yang ${ }^{1}$, Rui Gao ${ }^{1}$, Xiao Hui Xu¹ \& Xingbo Lu ${ }^{\star, 1}$ \\ ${ }^{1}$ Institute of Plant Protection, Shandong Academy of Agricultural Sciences, Shandong Key Laboratory of \\ Plant Virology, Jinan, Shandong, China
}

BioTechniques 65: 27-32 (July 2018) 10.2144/btn-2018-0056

Keywords: bias $\bullet$ lanthanide ions $\bullet$ polymerase chain reaction $\bullet$ preference

Rare earth elements have many uses, and are frequently included in products such as fluorescent materials, hydride batteries, catalytic materials and lasers. In this study, it was observed that trivalent lanthanide ions (Ln[III] ions) appeared to inhibit the synthesis of large fragments in PCR assays, thus resulting in the preferential amplification of shorter sequences. It is therefore speculated that this $\mathrm{Ln}(\mathrm{III})$ ion-mediated bias could be utilized to improve the success rates for amplification of shorter products.

\section{Introduction}

The PCR is a primer-mediated enzymatic amplification of target DNA fragments [1], whereby the production of target fragments increases at an exponential rate during the reaction. Thus, a trace amount of hereditary material can be amplified millions of times in a few hours for use in other applications, such as DNA sequencing [2], molecular diagnosis [3,4], and genetic analysis [5-7]. However, PCR introduces biases during amplification; for example, in the aptamer selection process [8-10], during multitemplate amplification [11], and in the amplification of sequences with extreme base compositions (sequences with mostly $\mathrm{G} / \mathrm{C}$ or A/T bases) [12-14]. Unfortunately, these problems are not fully understood, and in many cases, PCR is performed with little attention to bias issues. To obtain reliable data from PCR-based analyses, the elimination of PCR bias and artifacts is essential. Herein, we used an alternative approach in which we systematically defined the amplification bias and used it to improve the amplification success rates of shorter PCR products. We observed that the addition of lanthanide ions (Ln[III] ions) to the PCR system could gradually increase the proportion of shorter PCR products.
The lanthanides are the group of 15 elements with atomic numbers from 57 to 71 in the third subgroup of the periodic table. They have very similar chemical properties, such as a unique and stable oxidation state of +3 , and are therefore difficult to separate and purify from each other from within the minerals where they tend to be present. Despite their modest abundance, the biological activities of lanthanides have been fairly well studied. As a result, some lanthanide complexes are used in biomedical analyses, including as MRI contrast agents [15,16], and they are also effective catalysts for the hydrolytic cleavage of phosphate ester bonds [15,17]. Recently, a variety of lanthanide-based background-free luminescent bioassay methods have been developed, in view of their superior characteristics, including low toxicity, narrow emission bands and long-lived luminescence, among other things [18-20]. However, this is the first time that lanthanides have been shown to induce PCR bias resulting in a high proportion of shorter fragments.

\section{Materials \& methods \\ Reagents \\ $\mathrm{LaCl}_{3} \cdot 7 \mathrm{H}_{2} \mathrm{O}, \mathrm{CeCl}_{3} \cdot 6 \mathrm{H}_{2} \mathrm{O}, \mathrm{TbCl}_{3} \cdot 6 \mathrm{H}_{2} \mathrm{O}$, and $\mathrm{PrCl}_{3} \cdot 6 \mathrm{H}_{2} \mathrm{O}$ were purchased from}

Sigma-Aldrich (MO, USA). All primers were synthesized by Sangon Biotech Co. (Shanghai, China). Primer sequences are listed in Table 1. Taq DNA polymerase, $1 \times$ PCR buffer (containing $\mathrm{Mg}^{2+}$ ), and dNTPs were purchased from Takara Biotech Co. (Dalian, China).

DNA extraction \& preparation Genomic DNA was extracted from maize (Zea mays L.) and rice (Oryza sativa L.) using a Plant DNA Mini Kit (Omega Bio-tek Inc., GA, USA), according to the manufacturer's instructions. The extracted DNA was purified using a MicroElute DNA Clean Up Kit (Omega Bio-tek Inc.) and dissolved in double-distilled water $\left(\mathrm{dd}_{2} \mathrm{O}\right)$.

\section{PCR amplification}

PCR reactions were performed in 20- $\mu$ l volumes containing 1× PCR buffer, upstream and downstream primers for CaMV35S (500 nM each) or upstream primers $(500 \mathrm{nM})$ and downstream primers R1 and R2 (250 nM each) for the sucrose phosphate synthase-encoding gene (SPS), dNTPs (0.2 mM each), DNA template (50 ng), Ln(III) ions (dose-adjusted), DNA polymerase $(0.5 \mathrm{U})$, and $\mathrm{ddH}_{2} \mathrm{O}$ to $20 \mu \mathrm{l}$. In the multi-round PCR, the template was replaced with the amplification products obtained from the previous round, while all

\section{METHOD SUMMARY}

We found that when trivalent lanthanide ions ( $\mathrm{Ln}[\mathrm{III}]$ ions) were added to a PCR system in which more than two fragments were amplified, the synthesis of larger fragments (including smears) was inhibited, while the shorter fragments tended to be preferentially amplified. A Ln(III) ion-mediated PCR strategy could be used to inhibit the amplification of nonspecific highmolecular-weight products. 
Table 1. Sequences of primers used in this study.

\begin{tabular}{|l|l|l|}
\hline Name & Sequence (5'-3') & Size (bp) \\
\hline CaMV35S-F & GCTCCTACAAATGCCATCATTGC & 23 \\
\hline CaMV35S-R & GATAGTGGGATTGTGCGTCATCCC & 24 \\
\hline SPS-F & TTGGCACAGCAAGACACTCC & 20 \\
\hline SPS-R1 & TCGCCACTAACTAGACCATGAAGAC & 25 \\
\hline SPS-R2 & GTAATACGCAACCATGCAGGG & 21 \\
\hline
\end{tabular}

other reagents remained the same. PCR was performed in a Bio-Rad (CA, USA) thermal cycler using the following cycling protocol: $95^{\circ} \mathrm{C}$ for $5 \mathrm{~min}$, followed by 35 cycles of $95^{\circ} \mathrm{C}$ for $30 \mathrm{~s}, 58^{\circ} \mathrm{C}$ for $30 \mathrm{~s}$, and $72^{\circ} \mathrm{C}$ for $30 \mathrm{~s}$, with a final elongation at $72^{\circ} \mathrm{C}$ for 5 min.

\section{Gel electrophoresis}

PCR amplicons were collected and subjected to electrophoresis in an ethidium bromide/1.5\% (w/v) agarose gel for approximately $30 \mathrm{~min}$ at $120 \mathrm{~V}$.

\section{Results \& discussion}

The CaMV35S promoter from transgenic maize NK603 was selected for use in the model PCR system [21]. An enhancer is located upstream of the CaMV35S locus, and binding sites for the upstream primer were located in both the enhancer and the CaMV35S locus. The downstream primer bounds within the CaMV35S locus only. Thus, two different amplicons, $195 \mathrm{bp}$ and 450 bp in length, and a nonspecific product of 520 bp were amplified simultaneously in this reaction system (Supplementary Figure S1).

The effects of $\mathrm{Ln}(\mathrm{III})$ ions $\mathrm{La}^{3+}, \mathrm{Ce}^{3+}, \mathrm{Pr}^{3+}$ and $\mathrm{Tb}^{3+}$ on the PCR system were investigated. As shown in Figure 1, the 520-bp nonspecific band was no longer amplified in reactions supplemented with $\mathrm{La}^{3+}, \mathrm{Ce}^{3+}$, $\mathrm{Pr}^{3+}$ or $\mathrm{Tb}^{3+}$ at concentrations of $3.1 \mu \mathrm{M}$, $2.8 \mu \mathrm{M}, 2.0 \mu \mathrm{M}$ and $1.5 \mu \mathrm{M}$, respectively. After increasing the concentrations to 3.9-5.5 $\mu \mathrm{M}\left(\mathrm{La}^{3+}\right), 3.5-5.6 \mu \mathrm{M}\left(\mathrm{Ce}^{3+}\right)$, 2.8-5.2 $\mu \mathrm{M}\left(\mathrm{Pr}^{3+}\right)$ and 2.3-3.9 $\mu \mathrm{M}\left(\mathrm{Tb}^{3+}\right)$, the specific 450-bp band also disappeared, with only the 195-bp product remaining. Further increases in the concentrations of the $\operatorname{Ln}(\mathrm{III})$ ions gradually inhibited the synthesis of the 195-bp product, with amplification completely abolished at concentrations of $6.3 \mu \mathrm{M}, 6.3 \mu \mathrm{M}, 6.0 \mu \mathrm{M}$ and $4.7 \mu \mathrm{M}$, respectively. Therefore, the results showed that with increasing doses of $\operatorname{Ln}($ III) ions, the PCR system tended to favor the amplification of shorter products. However, the addition of $\mathrm{Ln}(\mathrm{III})$ ions to the system did not improve the specificity of the reaction.

To further verify that $L n(I I I)$ ions affect the proportions of each of the different PCR products on the basis of size, another duplex PCR model system was established. The sucrose phosphate synthase-encoding gene (SPS, GenBank accession number U33175.1) from rice was targeted for double amplification. Two specific products, $386 \mathrm{bp}$ and $233 \mathrm{bp}$ in length, were amplified in this system (Supplementary Figure S2). The 386-bp product was no longer amplified following the addition of any of the four $\mathrm{Ln}$ (III) ions at concentrations of 4.8-6.4 $\mu \mathrm{M}$ $\left(\mathrm{La}^{3+}\right), 3.3-5.1 \mu \mathrm{M}\left(\mathrm{Ce}^{3+}\right), 2.7-5.4 \mu \mathrm{M}\left(\mathrm{Pr}^{3+}\right)$ and 2.4-4.2 $\mu \mathrm{M}\left(\mathrm{Tb}^{3+}\right)$, with only the smaller fragment being amplified (Figure 2). When the concentrations of $\mathrm{Ln}(\mathrm{III})$ ions were increased to $7.1 \mu \mathrm{M}, 6.0 \mu \mathrm{M}, 6.3 \mu \mathrm{M}$ and $5.1 \mu \mathrm{M}$, respectively, amplification of the smaller product (233 bp) was also abolished, indicating complete inhibition of the amplification reaction. These results further proved that the $\mathrm{Ln}$ (III) ions have the ability to influence the composition of the PCR products, with a preference for shorter fragments. In addition, compared with the first assay, higher concentrations of $\operatorname{Ln}(\mathrm{III})$ ions were required in the second reaction system to produce an effect, which may be caused by differences in the DNA templates.

To further verify the effect of $\mathrm{Ln}$ (III) ions on PCR, a seven-round PCR (multi-round PCR) was attempted. However, when a small portion of the primary amplification mixture was used as template for the following round, smears always appeared on the agarose gel [22]. As shown in Figure 3, smears tended to accumulate in the second round, and no target products were obtained in the subsequent rounds. However, the amplification of shorter products was remarkably improved following the addition of $5.0 \mu \mathrm{M}$ $\mathrm{La}^{3+}$ for five rounds, which demonstrated that $\operatorname{Ln}(I I I)$ ions can inhibit the amplification of large and nonspecific products, which cause the smears, and improve the amplification of smaller products in multi-round PCR assays.
With the addition of $\operatorname{Ln}(\mathrm{III})$ ions to the reaction targeting the CaMV35S gene, the 520-bp nonspecific band was no longer amplified. Initially, it was speculated that the $\operatorname{Ln}(\mathrm{III})$ ions increased the specificity of PCR. However, increases in the concentration of Ln(III) ions also inhibited amplification of the specific 450-bp band, with only the shortest fragment selectively amplified in the reaction. Subsequently, a semiduplex PCR model, referred to as PCR2, was designed. When low concentrations of $L n(I I I)$ ions were added to the PCR, we observed that the specific 386-bp SPS product disappeared, while the smaller 233-bp-specific product continued to be amplified. The amplification of the smaller PCR products in the two models described above resembles a phenomenon known as the 'hormesis effect' [23], whereby short PCR products are amplified at low concentrations, but amplification at higher concentrations is inhibited.

There are several possible explanations for how $L n(I I I)$ ions shift the proportion of PCR products towards shorter fragments. The first possibility is the direct effect of Ln(III) ions on DNA. Lanthanides have incomplete $4 f$ electron shells, with empty f orbitals. According to the Pauli exclusion principle, each orbital needs to be filled with electrons with antiparallel spins to achieve saturation. Moreover, the $\mathrm{N}$ atom of the amino group and the $\mathrm{O}$ atom of the phosphate group of DNA molecules both have lone electron pairs. These lone pairs can form a perfect match with the empty f orbitals in the $\operatorname{Ln}(\mathrm{III})$ ions, such that the $\mathrm{Ln}(\mathrm{III})$ ions and the DNA molecules will form a stable complex. Tajmir-Riahi et al. reported that $\mathrm{Ln}(\mathrm{III})$ ions can chelate with the $\mathrm{PO}^{2-}$ group and the $\mathrm{N}-7$ position of guanine on the DNA chain, which perturbs $A / T$ base pairing. Therefore, higher concentrations of Ln(III) ions could have a significant impact on DNA structure [24]. Chen and Kang reported that $L n(I I)$ ions are capable of bonding to the DNA phosphate backbone via electrostatic interactions [25]. Based on these observations, it was postulated that during PCR, 

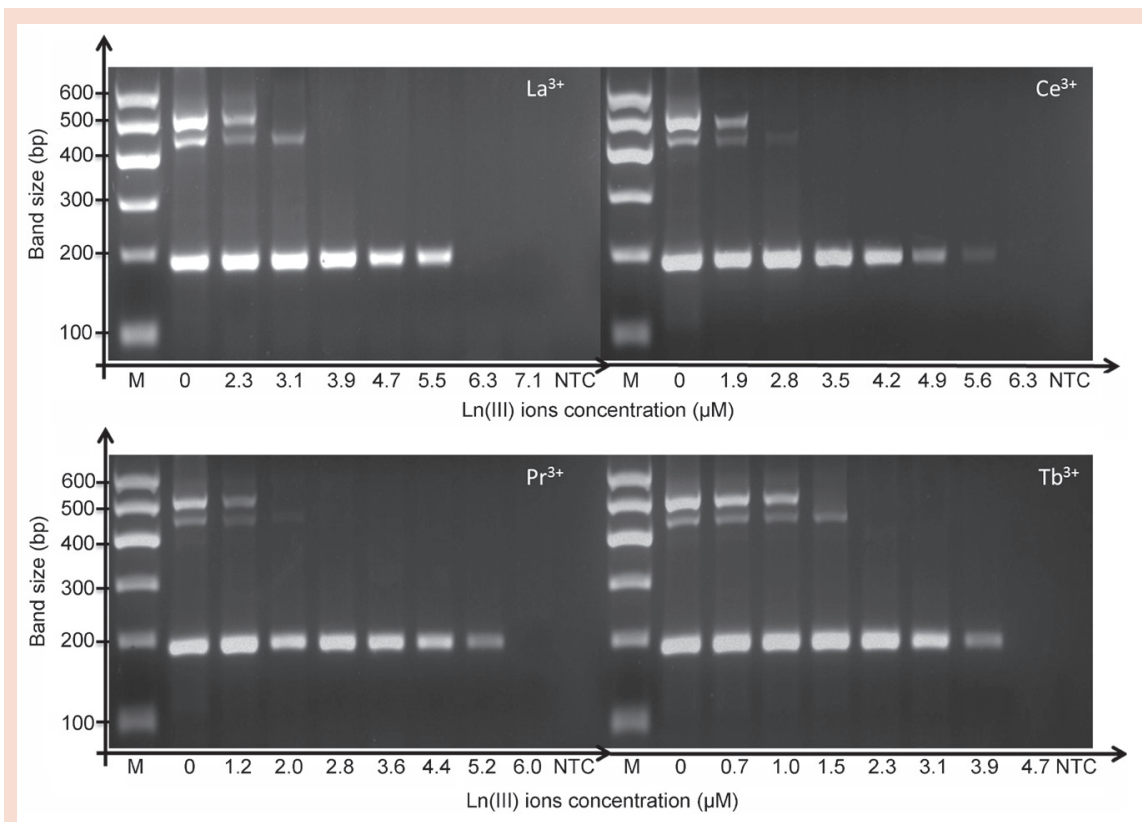

Figure 1. Gel electropherogram of CaMV35S amplicons from transgenic maize NK603 with/ without the addition of $\operatorname{Ln}(\mathrm{III})$ ions to the reaction system. The $x$-axis indicates the concentration of $\mathrm{Ln}(\mathrm{III})$ ions added to reaction mix, while the $y$-axis indicates the amplicon length. M: 100-bp DNA marker. Ln(III) ions were added at the following concentrations: La $^{3+}$ : 0, 2.3, 3.1, 3.9, 4.7, 5.5, 6.3 and $7.1 \mu \mathrm{M} ; \mathrm{Ce}^{3+}: 0,1.9,2.8,3.5,4.2,4.9,5.6$ and $6.3 \mu \mathrm{M} ; \mathrm{Pr}^{3+}: 0,1.2,2.0,2.8,3.6,4.4$, 5.2 , and $6.0 \mu \mathrm{M} ; \mathrm{Tb}^{3+}: 0,0.7,1.0,1.5,2.3,3.1,3.9$ and $4.7 \mu \mathrm{M}$.

the bonding of Ln(III) ions to DNA affected the structure of the DNA chain, thereby interfering with the binding of primers and DNA polymerase to the DNA strand. Furthermore, the longer the DNA strand,

the greater the number of bound Ln(III) ions, and thus the greater the impact; therefore, long-chain PCR products are the first to be inhibited. Ln(III) ions have also been known to promote Lewis acid cleavage of
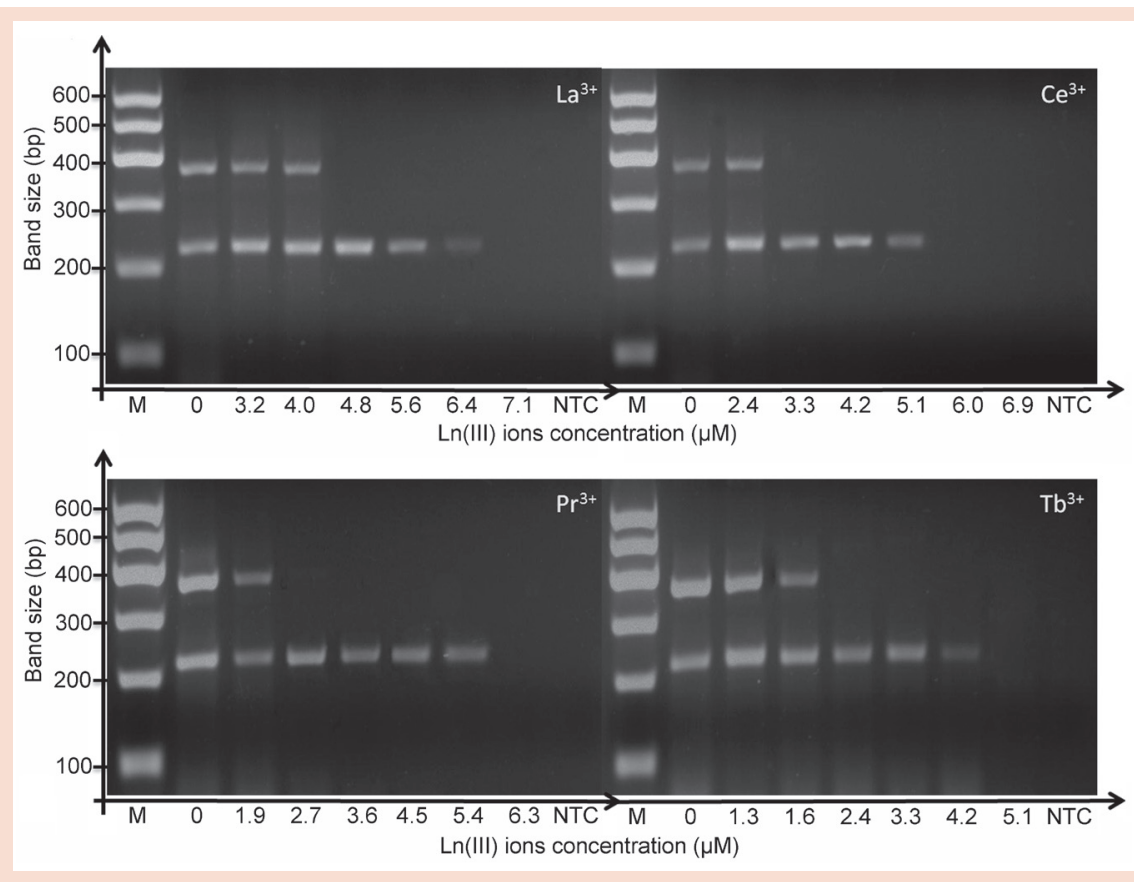

Figure 2. Gel electropherogram of SPS amplicons from rice with/without the addition of $\operatorname{Ln}(\mathrm{III})$ ions to the reaction system. The $x$-axis indicates the concentration of $\mathrm{Ln}$ (III) ions added to the reaction mix, while the $y$-axis indicates the amplicon length. M: 100-bp DNA marker. $\mathrm{Ln}(\mathrm{III})$ ions were added at the following concentrations: $\mathrm{La}^{3+}$ : 0, 3.2, 4.0, 4.8, 5.6, 6.4 and $7.1 \mu \mathrm{M} ; \mathrm{Ce}^{3+}: 0,2.4,3.3,4.2,5.1,6.0$ and $6.9 \mu \mathrm{M} ; \mathrm{Pr}^{3+}: 0,1.9,2.7,3.6,4.5,5.4$ and $6.3 \mu \mathrm{M} ; \mathrm{Tb}^{3+}: 0,1.3,1.6,2.4,3.3,4.2$ and $5.1 \mu \mathrm{M}$. phosphate esters and to enhance the rate of DNA-phosphate hydrolysis by seven orders of magnitude [16,26-29]. However, the effects of Ln(III) ions on DNA phosphodiester bond cleavage and hydrolysis are relatively mild, hence this factor was excluded as a possible cause of the inhibition observed in the current study.

Second, Ln(III) ions have a higher binding affinity for DNA polymerase compared with that of $\mathrm{Mg}^{2+}$, which might result in competitive binding with the enzyme during the reaction process. However, reducing the $\mathrm{Mg}^{2+}$ concentration in the PCR assay did not favor the amplification of small fragments (data not shown); therefore, this cause can be ruled out.

The third possible explanation is the effect of $L n(I I I)$ ions on Taq DNA polymerase. It was hypothesized that the interaction between Ln(III) ions and Taq DNA polymerase could play a dominant role in the preferential generation of shorter products. To investigate this, we measured the UV absorption spectra of $0.1 \mathrm{mg} / \mathrm{ml}$ of $\mathrm{Ln}(\mathrm{III})$ ions alone or $\mathrm{Ln}(\mathrm{III})$ ion-Taq polymerase complexes (data not shown). For absorption wavelengths in the range of 200-320 nm, Taq DNA polymerase had two absorption peaks at $222 \mathrm{~nm}$ and $276 \mathrm{~nm}$, respectively. The absorption peak at $222 \mathrm{~nm}$ correlated with the peptide bonds in Taq DNA polymerase, while the absorption peak at $276 \mathrm{~nm}$ corresponded to Tyr and Trp in the polymerase. As the concentration ratio between the rare earth ions and Taq DNA polymerase increased, the intensity of the two peaks decreased. This may have been caused by the effect of Ln(III) ions on oxygen- or nitrogen-containing amino acids, leading to a weakening of the existing strong bonds, subsequently causing the decrease in absorption. To test this hypothesis, different concentrations of bovine serum albumin (BSA) were added to the PCR system (Supplementary Figure S3). Longer products were observed with increasing BSA concentrations, which might be attributed to BSA displacing Taq DNA polymerase from the Ln(III) ions. These findings agree with previous studies, which indicate that BSA could be used to protect the activity of Taq DNA polymerase in PCR assays [30]. Furthermore, as shown in Figures 1 and 2, as the atomic number of the $\mathrm{Ln}(\mathrm{III})$ ions increased, the concentration of ions needed to enhance the amplification of smaller fragments decreased. This phenomenon might be related to lanthanide contraction; as the atomic 


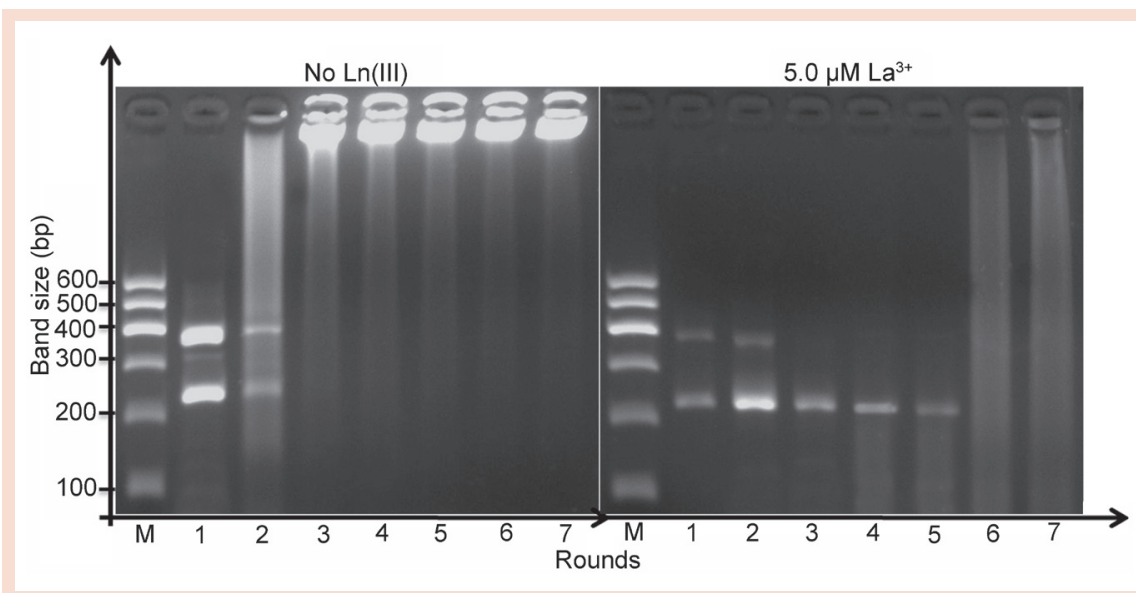

Figure 3. Gel electropherogram of products amplified during each round of a seven-round PCR assay with/without the addition of $\operatorname{Ln}(\mathrm{III})$ ions to the reaction system. The assay targeted the SPS gene from rice. The $x$-axis indicates the rounds of PCR, while the $y$-axis indicates the amplicon length. M: 100-bp DNA marker.

number increases, the ionic radius will gradually decrease. Smaller rare earth ions will have less steric hindrance, and hence can more easily react with protein macromolecules, thereby enhancing their binding to Taq DNA polymerase.

In conclusion, Ln(III) ions appear to inhibit the synthesis of larger PCR fragments, which results in a bias towards the amplification of shorter fragments. This preference did not appear to be related to the specificity of PCR. For molecular biology applications, this Ln(III) ion-mediated PCR strategy could be used in nonspecific PCR systems that amplify high-molecular-weight products.

\section{Author contributions}

$F L$ and $H S$ designed and performed experiments. SY, RG, XHX and $X L$ analyzed the data. FL and XHX wrote the paper. HS, SY, $R G$, and $X L$ revised the manuscript.

\section{Acknowledgments}

We thank Tamsin Sheen, PhD, from Liwen Bianji, Edanz Editing China (www.liwenbianji.cn/ac), for editing the English text of a draft of this manuscript.

\section{Financial \& competing interests disclosure}

This work was supported by the Youth Scientific Research Foundation of Shandong Academy of Agricultural Sciences (2014QNM46), the Young Talents Training Program of Shandong Academy of Agricultural Sciences, and the National Science and Technology Major Project of
China for Genetically Modified Organisms Breeding (2015ZX08013-003). The authors have no other relevant affiliations or financial involvement with any organization or entity with a financial interest in or financial conflict with the subject matter or materials discussed in the manuscript apart from those disclosed.

No writing assistance was utilized in the production of this manuscript.

\section{Open access}

This work is licensed under the Creative Commons Attribution 4.0 License. To view a copy of this license, visit http://creativecommons.org/licenses/by/4.0/

\section{Supplementary data}

To view the supplementary data that accompany this paper please visit the journal website at: www.future-science. com/doi/suppl/10.2144/btn-2018-0056

\section{References}

1. Saiki RK, Scharf S, Faloona F et al. Enzymatic amplification of beta-globin genomic sequences and restriction site analysis for diagnosis of sickle cell anemia. Science 230, 1350-1354 (1985).

2. Li H, Rothberg LJ. Label-free colorimetric detection of specific sequences in genomic DNA amplified by the polymerase chain reaction. J. Am. Chem. Soc. 126, 10958-10961 (2004).

3. Minunni M, Tombelli S, Fonti J et al. Detection of fragmented genomic DNA by PCR-free piezoelectric sensing using a denaturation approach. J. Am. Chem. Soc. 127, 7966-7967 (2005)

4. Tani H, Kanagawa T, Kurata S et al. Quantitative method for specific nucleic acid sequences using competitive polymerase chain reaction with an alternately binding probe. Anal. Chem. 79, 974979 (2007).

5. Erickson HS, Albert PS, Gillespie JW et al. Quantitative RT-PCR gene expression analysis of laser microdissected tissue samples. Nat. Protoc. 4, 902-922 (2009)

6. Ottesen EA, Hong JW, Quake SR, Leadbetter JR. Microfluidic digital PCR enables multigene analysis of individual environmental bacteria Science 314, 1464-1467 (2006).

7. Liu CN, Toriello NM, Mathies RA. Multichanne PCR-CE microdevice for genetic analysis. Anal. Chem. 78, 5474-5479 (2006).

8. Musheev MU, Krylov SN. Selection of aptamers by systematic evolution of ligands by exponentia enrichment: addressing the polymerase chain reaction issue. Anal. Chim. Acta 564, 91-96 (2006).

9. Cho M, Xiao Y, Nie J et al. Quantitative selection of DNA aptamers through microfluidic selection and high-throughput sequencing. Proc. Nat Acad. Sci. USA 107, 15373-15378 (2010)

10. Acinas SG, Sarma-Rupavtarm R, Klepac-Ceraj V, Polz MF. PCR-induced sequence artifacts and bias: insights from comparison of two $16 \mathrm{~S}$ rRNA clone libraries constructed from the same sample. Appl. Environ. Microbiol. 71, 8966-8969 (2005).

11. Kanagawa T. Bias and artifacts in multitemplate polymerase chain reactions (PCR). J. Biosci. Bioeng. 96, 317-323 (2003).

12. Pan W, Byrne-Steele M, Wang $\mathrm{C}$ et al. DNA polymerase preference determines PCR priming efficiency. BMC Biotechnol. 14, 10 (2014).

13. Dohm JC, Lottaz C, Borodina T, Himmelbauer H. Substantial biases in ultra-short read data sets from high-throughput DNA sequencing. Nucleic Acids Res. 36, 105 (2008).

14. Hansen KD, Brenner SE, Dudoit S. Biases in Illumina transcriptome sequencing caused by random hexamer priming. Nucleic Acids Res. 38, 131 (2010).

15. Aime S, Crich SG, Gianolio E, Giovenzana GB, Tei L, Terreno E. High sensitivity lanthanide(III) based probes for MR-medical imaging. Coordin. Chem. Rev. 250, 1562-1579 (2006).

16. Reji TFAF, Pearl AJ, Rosy BA. Synthesis, characterization, cytotoxicity, DNA cleavage and antimicrobial activity of homodinuclear lanthanide complexes of phenylthioacetic acid. J. Rare. Earth. 31, 1009-1016 (2013)

17. Franklin SJ. Lanthanide-mediated DNA hydroIysis. Curr. Opin. Chem. Biol. 5, 201-208 (2001).

18. Liu Y, Tu D, Zhu H, Ma E, Chen X. Lanthanidedoped luminescent nano-bioprobes: from fundamentals to biodetection. Nanoscale 5 , 1369-1384 (2013).

19. Liu Y, Tu D, Zhu H, Chen X. Lanthanide-doped luminescent nanoprobes: controlled synthesis, optical spectroscopy, and bioapplications. Chem. Soc. Rev. 42, 6924-6958 (2013).

20. Huang P, Tu D, Zheng W, Zhou S, Chen Z, Chen X. Inorganic lanthanide nanoprobes for background-free luminescent bioassays. Sci. China Mater. 58, 156-177 (2015).

21. Kamle S, Kumar A, Bhatnagar RK. Development of multiplex and construct specific PCR assay for detection of cry2Ab transgene in genetically modified crops and product. GM Crops 2, 74 81 (2011).

22. Bell DA, DeMarini DM. Excessive cycling converts PCR products to random-length higher 
molecular weight fragments. Nucleic Acids Res. 19, 5079 (1991).

23. Calabrese EJ, Dhawan G, Kapoor R, lavicoli I, Calabrese $\mathrm{V}$. What is hormesis and its relevance to healthy aging and longevity? Biogerontology 16, 693-707 (2015).

24. Tajmir-Riahi HA, Ahmad R, Naoui M. Interaction of calf-thymus DNA with trivalent $\mathrm{La}$, Eu, and Tb ions. Metal ion binding, DNA condensation and structural features. J. Biomol. Struct. Dyn. 10, 865-877 (1993)

25. Chen J, Kang J. Interaction between Eu(bpy $)_{3}{ }^{3+}$ complex and DNA by fluorophotometry. J. Rare Earth. 21, 53-55 (2003).

26. Rammo J, Hettich R, Roigk A, Schneider HJ. Catalysis of DNA cleavage by lanthanide complexes with nucleophilic or intercalating ligands and their kinetic characterization. Chem. Commun. 1, 105-107 (1996).
27. Rammo J, Schneide HJ. Supramolecular Chemistry, 62. Ligand and cosubstrate effects on the hydrolysis of phosphate esters and DNA with lanthanoids. Liebigs Ann. 11, 1757-1767 (1996).

28. Roigk A, Hettich R, Schneider HJ. Unusual catalyst concentration effects in the hydrolysis of phenyl phosphate esters and of DNA: a systematic investigation of the lanthanide series. Inorg. Chem. 37, 751-756 (1998).

29. Mohanan K, Aswathy R, Nitha LP, Mathews NE, Kumari BS. Synthesis, spectroscopic characterization, DNA cleavage and antibacterial studies of a novel tridentate Schiff base and some lanthanide(III) complexes. J. Rare Earth. 32, 379-388 (2014).

30. Kreader CA. Relief of amplification inhibition in PCR with bovine serum albumin or T4 gene 32 protein. Appl. Environ. Microbiol. 62, 1102-1106 (1996).
First draft submitted: 16 January 2018; Accepted for publication: 29 May 2018

Address correspondence to: Xingbo Lu; Institute of Plant Protection, Shandong Academy of Agricultural Sciences, Shandong Key Laboratory of Plant Virology, Jinan, Shandong, China; Tel.: +86 053 6665 9095; E-mail: luxb99@sina.com

${ }^{\ddagger}$ Fan Li and Hongwei Sun contributed equally to this work.

To purchase reprints of this article contact: s.cavana@future-science.com

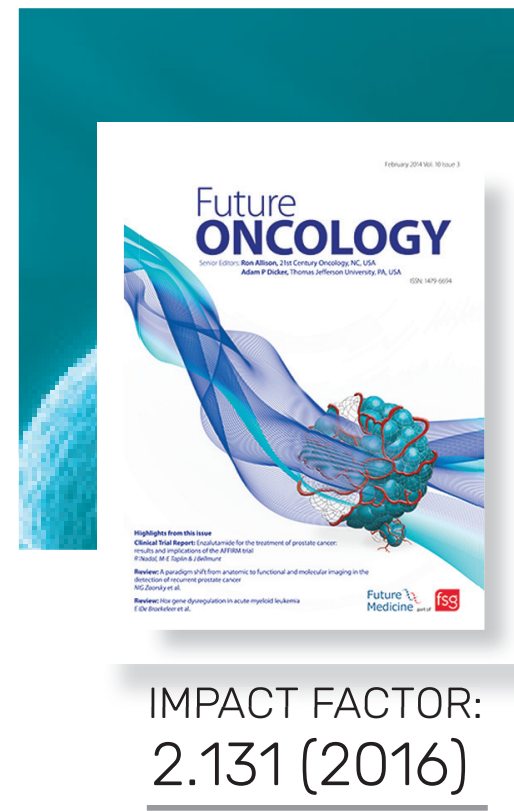

www. futuremedicine.com
To claim your free trial, contact us at: trials@futuremedicine.com
Future $\%$ an imprint of Medicine
MEDLINE/Index Medicus, EMBASE/Excerpta Medica, Chemical Abstracts, $\mathrm{CINAHL}^{\circledR}$ Plus, Science Citation Index Expanded ${ }^{\mathrm{m}}$ (SciSearch ${ }^{\circledR}$ ), Journal Citation Reports/Science Edition ${ }^{\circledR}$, Current Contents ${ }^{\circledR} /$ Clinical Medicine, Scopus ${ }^{\circledR}$

ISSN: 1479-6694

Frequency per year: 30

INDEXING

\section{Future Oncology}

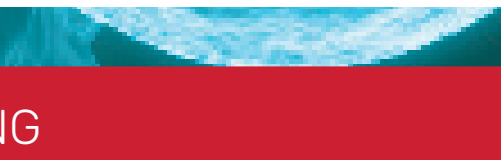

